\title{
US state legislation on biosimilars substitution
}

\section{Despite the fact that US Food and Drug Administration has yet to receive a biosimilars application, many US states have been considering legislation which could potentially limit biosimilars substitution.}

Keywords: biologicals, biosimilars substitution, state legislation

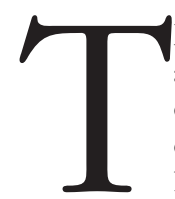

he Biologics Price Competition and Innovation Act (BPCI Act) of 2009 was signed into law on 23 March 2010 by President Barack Obama. The BPCI Act establishes an abbreviated approval pathway for biological products that are demonstrated to be 'highly similar' (biosimilar) to, or 'interchangeable' with, an FDA-approved biological product.

Unlike in Europe, where the European Medicines Agency (EMA) does not have the authority to designate a biosimilar as interchangeable; the US Food and Drug Administration (FDA), under the BPCI Act, has this authority.

FDA is still in the process of developing guidelines regarding biosimilars, however, despite the fact that these guidelines are still not finalized, many US states are considering, or have introduced, laws related to the substitution of biosimilars at the retail pharmacy level.

These state laws will establish procedures on how biosimilars substitution may be carried out at the retail pharmacy level and detail requirements for informing the patient and the prescribing physician, as well as for record keeping when substitution of a prescribed originator biological with an interchangeable biosimilar takes place. Such state laws also exist for certain generic drugs, e.g. anti-epileptics, drugs with a narrow therapeutic index; which require physician notification; but the requirements being proposed for biosimilars appear to be more stringent. Although the bills support the use of biosimilars in the US, some believe the requirements may impose unnecessary, burdensome, and potentially costly, requirements on retail pharmacists when dispensing biosimilar drugs already approved as interchangeable by FDA. Such procedures, incorporating recording software, informing patients and the prescribing physician, for track and trace purpose are already in place at the hospital pharmacy level.

Biotech giants Amgen and Genentech have been criticized for backing the US state bills. Amgen, however, has stated that the company believes that the bills enhance safety monitoring and transparency of substituted biologicals and are therefore in the interest of patient safety [1]

Six US states: Arizona, Arkansas, Maryland, Mississippi, Texas and Washington, have declined to pass the biosimilars legislation.

Five other states: California, Colorado, Illinois, Massachusetts and Pennsylvania, however, are still considering legislation on the substitution of biosimilar drugs for brand-name biologicals. Florida and North Dakota have passed legislation

\section{Figure 1: Distribution of top biologicals in the US by total unit volume}

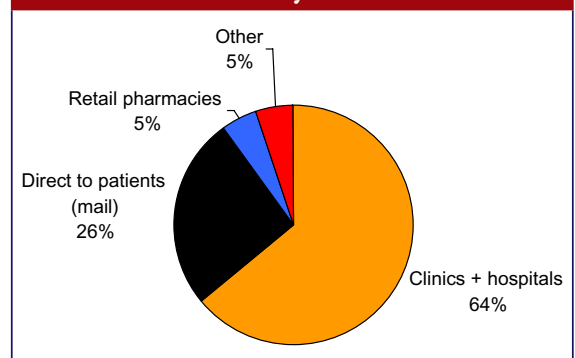

Top biologicals are defined as those constituting $1 \%$ or more of the total biologicals sales. These make up $83.7 \%$ of the total market. The products represented include: Aranesp, Avastin, Avonex, Avonex Pen, Beaseron, Enbrel, Epogen, Erbitux, Herceptin, Humira, Lucentis, Neulasta, Neupogen, Orencia, Pegasys, Pegasys Conv. Pack, Pegasys Proclick, Procrit, Rebift, Remicade, Rituxan, Stelara, Synagis, Xgeva, Xolair, Yervoy.

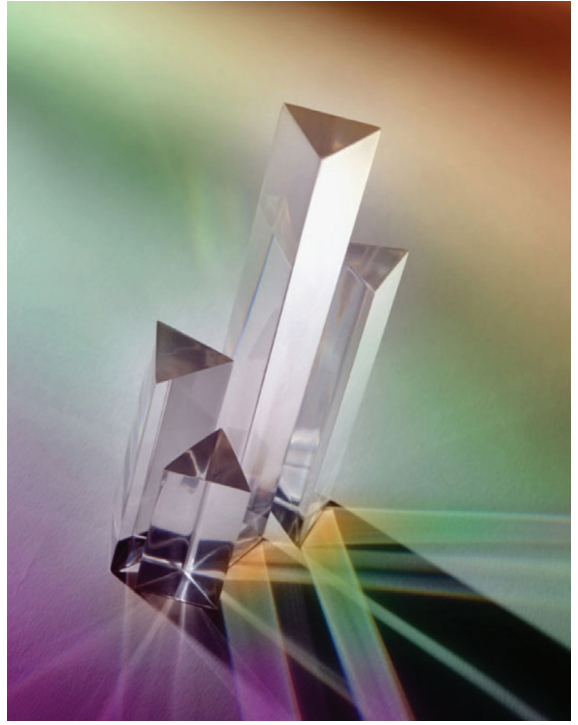

requiring notification and record keeping for biosimilars. Oregon, Utah and Virginia have also passed such a law, but with a sunset clause on the physician notification provision, which is likely to expire before any biosimilars are approved in the US.

Most of the proposed bills require the retail pharmacist to notify the prescribing physician of a biosimilar substitution, but the timelines for notification vary from within 24 hours in Indiana to within 10 days in Florida, see Table 1. Most of the legislation under consideration also requires the retail pharmacist to retain a record of the biosimilar substitution, but again the length of time that such records have to be kept varies from two to 10 years, see Table 1 .

The wording in the different state legislation varies, but is similar to that of Arizona:

'The pharmacist notifies the medical practitioner of the substitution in writing or electronically within 72 hours, including the name and manufacturer of the dispensed interchangeable biosimilar product. This requirement is satisfied if the substitution information is entered into an electronic system between prescribing medical practitioners and pharmacists, including electronic medical records.

The pharmacy retains a written or electronic record of the substitution for at least seven years after the date of the substitution.' 
Table 1: US state legislation on biosimilars substitution

\begin{tabular}{|c|c|c|c|c|}
\hline State* & Status ${ }^{* *}$ & Key votes & $\begin{array}{l}\text { Physician notification } \\
\text { period (after substitution) }\end{array}$ & $\begin{array}{l}\text { Record- } \\
\text { keeping } \\
\text { period }\end{array}$ \\
\hline Arizona & Not enacted & Passed Senate committee & 3 days & 7 years \\
\hline Arkansas & Not enacted & None & 3 days & 2 years \\
\hline California $^{1,2}$ & $\begin{array}{l}\text { Under consideration by the } \\
\text { Governor }\end{array}$ & $\begin{array}{l}\text { Passed Senate chamber and several } \\
\text { House committees }\end{array}$ & 5 days & 3 years \\
\hline Colorado & Not enacted & Passed House chamber & 3 days & 5 years \\
\hline Delaware $^{1}$ & Not enacted & None & 2 days & 3 years \\
\hline Florida $^{3}$ & Enacted & & $\mathrm{N} / \mathrm{A}$ & 2 years \\
\hline Illinois $^{1}$ & Under consideration & None & 5 days & 5 years \\
\hline Indiana & Not enacted & Senate passed Study Resolution & 5 days & 5 years \\
\hline Maryland & Not enacted & Passed Senate chamber & 5 days & 5 years \\
\hline Massachusetts $^{1,2}$ & Under consideration & None & Reasonable time & 1 year \\
\hline Mississippi & Not enacted & None & 5 days & 10 years \\
\hline North Dakota & Enacted & & 1 day & 5 years \\
\hline Oregon & Enacted & & 3 days & 3 years \\
\hline Pennsylvania $^{1}$ & Under consideration & None & 3 days & 5 years \\
\hline Texas & Not enacted & $\begin{array}{l}\text { Passed Senate chamber and House } \\
\text { committee }\end{array}$ & 3 days & 2 years \\
\hline Utah & Enacted & & 3 days & 5 years \\
\hline Virginia & Enacted & & 5 days & 2 years \\
\hline Washington $^{1}$ & Not enacted & None & 3 days & 2 years \\
\hline
\end{tabular}

The Generic Pharmaceutical Association (GPhA) believes that any laws concerning biosimilar substitution are 'premature and unnecessary at this time'. FDA has also defended the substitution of interchangeable biosimilars, with FDA Commissioner Margaret Hamburg saying that attempts to undermine trust in biosimilars are "worrisome and represent a disservice to patients who could benefit from these lower-cost treatments' [2].

The Biotechnology Industry Organization (BIO), which represents originator biologicals manufacturers, is in favour of the state bills saying that such legislation 'properly preserves the physician-patient relationship, protects patient access to accurate prescription information, maintains incentives for innovation and promotes a competitive market for biological therapies.'
But is there really any issue at all concerning these state bills? Only around 5\% of the total unit volume of top biologicals in the US is distributed by retail pharmacies, see Figure 1 . The remaining $95 \%$ is administered by a healthcare provider, e.g. in hospitals, physician offices, long-term care facilities, prisons, via home healthcare, or mailed directly to patients. Since around $26 \%$ of top biologicals are distributed through mail order, the impact of these state bills may depend on how they regulate mail-order pharmacies. Therefore, the issue may be whether the state bills include such pharmacies in their provisions for biological substitutions, which would result in almost one third of biologicals will be covered by the legislation.

\section{Competing interests: None.}

Provenance and peer review: Article prepared based on extensive research; internally peer reviewed.

Michelle Derbyshire, PhD, GaBI Online Editor

\section{References}

1. GaBI Online - Generics and Biosimilars Initiative. Amgen's response to biosimilar substitution legislation in US [www.gabionline.net]. Mol, Belgium: Pro Pharma Communications International; [cited 2013 Jul 5]. Available from: www.gabionline.net/ Biosimilars/News/Amgen-s-response-to-biosimilarsubstitution-legislation-in-US

2. GaBI Online - Generics and Biosimilars Initiative. US FDA defends biosimilar substitution [www gabionline.net]. Mol, Belgium: Pro Pharma Communications International; [cited 2013 Jul 5]. Available from: www.gabionline.net/Biosimilars/General/USFDA-defends-biosimilar-substitution

DOI: 10.5639/gabij.2013.0203.040

Copyright @ 2013 Pro Pharma Communications International 